\title{
Continuing the debate on the philosophy of modern public health: social quality as a point of reference
}

\author{
Laurent J G van der Maesen, Harry G J Nijhuis
}

\section{Our 1994 invitation reviewed}

In the second edition of 1999 of this journal Douglas Weed commented on our 1994 initiative to stimulate discussion on the philosophical foundations of public health. ${ }^{12}$ We are pleased with Douglas Weed's response. It enables us to develop our own views and take new steps. The unacceptable state of health in numerous countries around the world forces us to question old and new approaches in public health and policies associated with public health. ${ }^{3}$ We will reflect on various aspects of Douglas Weed's article and do so with reference to new conceptualisations of the notions of public and health as they relate to the concept of social quality.

In our 1994 contribution, we argued that mainstream epidemiology increasingly serves as a tool of molecular biology, and that consequently, social epidemiology tends to become a contradiction in terms. We state here in advance, however, that we do not criticise the significance of this scientific work in the context of medical policies, but we do have questions regarding it as the scientific cornerstone of modern public health. In 1994, the Lancet editors concluded that common epidemiological research has always been based on simplistic notions of causality. ${ }^{4}$ Reference was made to the Leeds Declaration of 1993, which states that traditional epidemological methods are too blunt to dissect the complexities of today's health problems. ${ }^{5}$ The Research Unit in Health and Behavioural Chance at Edinburgh University concluded that mainstream epidemiology has little to offer in modernising public health, that its positivistic orientation underscores a principal weakness in its understanding of the social dynamics of health and disease, therefore undermining its ability to effect change in public health. ${ }^{6}$

The fundamental issue concerns what we precisely mean by the causes and effects in modern public health issues. This point was discussed by Adrian Renton, who stated that mainstream epidemiology has led to an overemphasis on the problems of inferential logic at the expense of an analysis of what we understand by diseases and causes. ${ }^{7}$ It is possible that the practical implications of this are what led the Institute of Medicine to conclude that the United States has lost sight of its public health goals and has allowed the public health system to fall into complete disarray. ${ }^{8}$

Nancy Krieger, in an endeavour to find an alternative course, presented a new perspective as well as a historical overview of related meth- odological debates. In the 1960s, MacMahon introduced his web of causation to conceptualise a multi-factored aetiology of disease, questioning existing simplistic notions of causality. Krieger, however, queried whether "anyone had seen the spider" in the web of causation. The web model, in her judgement, cannot deliver a coherent theory to explain multiple causation. She concluded that the introduction of it and subsequent related research failed to "differentiate between determinants of disease in individuals and in populations". ${ }^{9}$ The Lilienfelds, in their standard textbook on epidemiology, suggest that statistical, mathematical techniques are crucial in the development of knowledge about the nature, variations and prevalence of diseases. It is precisely in this suggestion that the problem lies. For the Lilienfelds, theoretical considerations also remain limited to methodological issues. $^{10}$

According to Krieger, one of the few people who have tried to develop a coherent aetiological theory is Thomas McKeown, who explains that historically, transitions in environment have been significantly more important for people's health than medical interventions. ${ }^{11}$ Krieger points out that 10 years later, $\mathrm{McKe}$ own's aetiological hypothesis is a far cry from the web causation theory. Focusing on the health effects of agriculture, urbanisation and industrialisation simultaneously directs us to consider broad population shifts in disease occurrence and whether the proximate causes of a particular disease operate before or after birth and if they exert their effects via depriving the body of basic biological requirements or by exposing the body to types or levels of substances, hazards, or conditions not anticipated through natural selection. ${ }^{12}$ In her analysis of McKeown's work, Krieger found that in his scenario, the responsible parties are still absent. Instead, natural selection is the decisive player in the evolution of health. ${ }^{13}$ Krieger proposed a new socioecological model to generate knowledge concerning the aetiology of patterns of population health, disease, and well being. ${ }^{14}$ Two years later, the Sussers also defended ecoepidemiology as a new paradigm. ${ }^{15}$ Their aim was to integrate multiple levels of causality inherent to the processes that affect human health. In other words, they advocate crossing scientific boundaries to be able to address the reciprocity of aetiological processes in health. The limitations inherent in the web of causation are the reason we need a new paradigm. The web model is in fact a black box 
paradigm and by limiting the subject matter of public health to the epidemiological point of view, it in fact only generates inertia. ${ }^{16}$

\section{Health, public and social quality}

In both the theoretical and the methodological sense, epidemiology generally is perceived as the main scientific source for public health issues. The philosophical question, however, is just what do we mean by public health? To answer this, we must first conceptualise the notions of health and public.

HEALTH

In both theory and practice, health is not generally perceived as a notion as such. It is commonly seen as a state in relation to the absence of disease, and not further defined as such. Disease refers to a dysfunctional somatic or psychological state in individual subjects. In the 1980s, Canada played a crucial part in developing modern conceptualisations of health. The Ottawa Charter underscored the need to work on positive social conditions for the health of citizens. ${ }^{17}$ In the 1987 Evans Report, the concept of health was explicitly changed from a state of absence of disease to the physical and mental ability of subjects to develop and maintain a satisfactory life in relation to relevant, positive living conditions. ${ }^{18}$ This conceptualisation, in our interpretation, is relative. It does not refer to an ideal state of health. Health can also refer to the condition of invalidated or chronically diseased persons able to sustain a satisfactory way of life. To promote personal health in communities, the Evans Report cites seven values that must be tackled: equity, quality, comprehensiveness, informed choice, accountability, cost effectiveness and commitment to the future. The Canadian initiative took a positive approach to defining health became the original inspiration for the Healthy Cities Project of the World Health Organisation.

Len Doyal and Ian Gough define health as one of the basic personal human needs. They also present indicators and instruments for measuring outcomes in tackling these needs. ${ }^{19}$ In line with their theory, our proposition is that health is primarily an attribute of individual subjects. Notions such as healthy communities or healthy populations evoke confusion. A healthy population metaphorically refers to a population who is doing well, culturally and economically. As a concept, "population health" is confusing. It suggests collective health as an outcome of economic, cultural and political processes and configurations.

According to Ronald Frankenberg, the western concept of health as the absence of disease or organic dysfunctionality leaves little room for scientific consideration of personal perceptions or for the role of constituent biographical factors, either for health or for its negative counterpart, illness. Similarly, little attention is paid to social dimensions on the micro, meso or macro levels. ${ }^{20}$ Referring to Jürgen Habermas, Harry Nijhuis called attention to this downplaying of both the personal (illness) and the social (sickness) perspectives. ${ }^{21}$ If these are to be resolved, the scientific rationality that domi- nates modern medicine appears to be too limited to support a full comprehension of health and its negative counterparts. According to Habermas, the personal and social reality of health should be approached through a broader, three dimensional rationality concept. ${ }^{22}$ In this concept, the evolution of the personal (subjective) and social (normative) dimensions of health should be valued equally with its technical (objective) aspects. In addition, Robert Beaglehole and Ruth Bonita state that modern problems of public health, such as increasing inequality, explosive global population growth, new forms of exclusion and the dissolution of traditional forms of social cohesion must be re-asesssed with this three dimensional rationality in mind. ${ }^{23}$

In her study of lay concepts of health and illness, Blaxter demonstrates that the British generally support the contents of the new Canadian approach to promoting health, as it was put into practice in the Healthy Cities Project. ${ }^{24}$ The personal lifestyles of people, however, became the primary focus of the project. It moved away from its original principles and in the practical sense, basically adopted an enlightened approach that was wholly individually orientated. According to Fran Baum, the Healthy Cities Project, "As set out in the Ottawa Charter, suffers in its translation to a practical project." ${ }^{25}$ Most of the collectivist elements vision of in the Ottawa Charter vision, with its emphasis on promoting health through state policy intervention, action Groups, (rather than individuals), involvement of lay persons (rather than professionals) and the creation of environments that make healthy choices easy choices, was lost in favour of strategies aiming at individual behaviour change. According to Van der Maesen new directives for the future of the Healthy Cities Project should as a rule be based on a thorough evaluation of processes and results from the original principles of this project. And that is not the case. ${ }^{26}$

PUBLIC AND SOCIAL QUALITY

In our conceptualisation of public health, public is synonymous with larger social configurations (communities) of subjects that interact. The reciprocity between social structures and individual subjects is crucial. The social, political, economic and cultural conditions for interaction are in a sense given, but the result of the interactions in turn also changes the conditions. In other words, for a complete picture of the world of human beings, we must distinguish between structural aspects and human action. In the words of Roy Bhaskar, the public, or society, is "both the ever-present condition (material cause) and the continually reproduced outcome of human agency. And praxis is both work, that is conscious production, and (normally unconscious) reproduction of the conditions of production, that is society. One can refer to the former as the duality of structure, and the latter as the duality of praxis. ${ }^{27}$ In simpler terms, society forms people who then transform and reproduce society. This ontology concerns the transformational nature of 
societies and communities. Interacting subjects are perceived as social beings, not as atomised or isolated persons. Lucien Sève concludes, somewhat exaggeratedly, that psychology by no means holds the secret of human affairs, "simply because this secret is not of a psychological order. This secret is the ensemble of social relations." 28

In his vision of humans as social beings, he agrees with Jean Piaget, for whom the development of formal structures in adolescence is not only linked to maturation of cerebral structures. A particular social environment remains indispensable for the realisation of the psyche of the adolescent. ${ }^{29}$ For our concept of public health, social processes are perceived as outcomes of the reciprocity between social systems and the social actions of interacting subjects. We need mediating concepts to analyse the multi-layered dimension of this reciprocity. For Klaus von Beyme, modern sociological theories are still restricted to either a behavioural approach from an individualistic point of view, or to social systems from the point of view of social structure. ${ }^{30}$ The challenge for a modern concept of public health is among others to connect both perspectives, both domains.

If subjects are influenced and even formed by social conditions, it is necessary that social policy evaluate these conditions. We propose that the conditions of configurations of interacting subjects, for example communities, specific urban environments, and so on, be assessed in terms of social quality. In 1997 a large group of European scientists argued that a theoretical debate should be opened on the quality of the social in Europe, in other words, the social quality of living conditions, environments, systems and institutions. They defined social quality as "the extent to which citizens are able to participate in the social and economic life of their communities under conditions which enhance their well being and individual potential. In order to be enabled to participate (or to enjoy at least a minimum level of social quality), citizens have (i) to have access to an accepted minimum level of economic security, (ii) to experience a basic level of social inclusion, (iii) to live in a community which exhibits social cohesion and (iv) to be empowered to develop their competencies." 31 It is our opinion that the concept of social quality paves the way for connecting public (referring to the collective) and health (referring to the individual). According to Bhaskar, this is a theoretical necessity "encompassing both aspects of the duality of praxis ... between human agency and social structure. Such a point, linking action to structure, must both endure and be immediately occupied by individuals." ${ }^{93} \mathrm{He}$ calls this the mediating system. With this in mind, social quality in general concerns the reciprocity between the operations of institutions or organisations (representing social structures) and the interaction of subjects (representing human agency). These outcomes determine the nature of the conditions and the circum- stances in which - and with which-subjects have to live and to develop their health. ${ }^{34}$

PUBLIC HEALTH

Based on this theoretical background, we can further explore the subject matter of modern public health. Health related social quality refers to the conditions, circumstances and social systems (institutions, organisations) that improve or undermine health, as conceived in the Evans Report. Social quality in this perspective refers to the nature of health related conditions resulting from the reciprocity between subjects and the relevant social systems, such as educational institutions, cultural systems, economic systems, the labour market and so on. Health care systems, including hospitals, extramural health services, medical industries, insurance companies, etc, should here also be seen as social systems that function as sources for people's health. In the context of medical policies, quality primarily refers to the efficacy and the ethical aspects of individual medical interventions. In the context of modern public health, the focus should be on the social quality of living conditions, circumstances and systems, including care systems. Social quality aspects of health care systems are for example, socially equitable distribution of services, their availability, accessibility and their capacity for empowerment.

Given this subject matter, modern public health now presents three strategies: (1) improving social conditions that stimulate health, (2) preventing social conditions that threaten health, and (3) neutralising existing social conditions that cause ill health. With this conceptual framework, we can explain the theory with which the seven values of the Evans Report need to be tackled to promote the health of citizens. The introduction of social quality as a basic concept also eradicates the inconsistency of statements about the health of communities. In our terminology, populations that are usually referred to as healthy have in more adequate words a high degree of social quality.

Douglas Weed discussed screening for cancer as an aspect of public health policy. According to our concept of public health, he would certainly be correct to do so if screening considered the hygienic or social conditions related to the aetiology of cancer. He would also be right if he discussed the social quality aspects of screening, such as the availability and accessibility of this health facility for those who are in need of it, and he would be correct again in investigating apparent social policy choice of investing in cancer screening instead of educating children or providing hospital care. If his focus on screening, however, is limited solely to the debate about the effectiveness or side effects of medical procedures for early diagnosis of cancer to achieve timely treatment of such diseases, we would sooner be speaking of medical policy, not public health policy.

\section{Reviewing theoretical perspectives}

Commenting on the polarisation of appropriate (epidemiological) methods for studying public health problems, Fran Baum advocates the application of a range of methods to fully 
comprehend the problems. In her words, "Public health researchers are most effective when they are eclectic in the choice of methods." ${ }^{35}$ In contrast with Baum's supposition, we do not agree that the debate about the application of quantitative and/or qualitative methods reaches the core of the crisis in modern public health. Rather, the heart of the matter is the choice of ontological perspectives. In our 1994 editorial, for the sake of argument, we presented a rather simplistic scheme of ontologies and, based on the opus magnum of Viktor Vanberg, distinguished two basic patterns in current Western thought, the individualistic and the collectivist. ${ }^{36} \mathrm{~A}$ more refined scheme of ontologies and epistemologies is needed for an in depth debate on a philosophy of modern public health. We will present and explain four basic patterns of thought that underlie possible theoretical approaches to public health. This scheme of socio-philosophical perspectives is derived from a study by Laurent van der Maesen on the transformation of health services in the Netherlands. ${ }^{37}$

THE PARETO PATTERN

The first thought pattern refers to the mechanistic-atomistic, utilitarian ontology, following the propositions of the Anglo-Saxon moral philosophers, such as Hobbes, Locke and Hume, with the economist Pareto, as their very pronounced exponent. This ontology is connected to a positivistic (empiricist), individualistic epistemology. ${ }^{38}$ This pattern (as is the Durkheim pattern) is considerably influenced by the biophysical sciences that evolved together with Cartesian interpretations. ${ }^{39}$ It underlies, for example, present day economic, sociological and medical sciences. In Roy Bhaskar's terms, "There is in fact one body of social doctrine, whose avatars include utilitarianism, liberal political theory and neo-classical economic theory, which does conform to individualistic prescriptions, on the assumption that what is in effect a generalised aggregation problem can be solved." ${ }^{40}$ According to Jozef Schumpeter, this ontology therefore paved the way for the methodological individualism that supposes that complexity is non-existent. Complex configurations must be resolved into the parts that constitute this whole as an aggregation. ${ }^{41} \mathrm{~A}$ remarkable fact in this respect is that in the 1930s, the physiologist Henderson introduced Pareto to such social scientists as Parsons and Merton in the United States. Henderson's intention was to demonstrate the intrinsic affinity between the scientific approaches in understanding biophysics and in understanding and influencing economical, political and sociological tendencies. ${ }^{42}$

THE WEBER PATTERN

The second pattern concerns the intentionalistic, voluntaristic ontology that refers to the work of Kant, with Weber as its most outspoken exponent. This pattern is connected with a hermeneutics orientated, individualistic epistemology. In contrast with the first pattern, Weber emphasised the essential difference in the nature of the physical sciences and the social sciences. The first should be approached through positivistic sciences (see epidemiology). The latter concerns the a priori intentionality of human actions, which can only be understood through the hermeneutic application of methodological individualism. Between objective facts and human actions, there is no direct correspondence, determination or reflection. According to Wright Mills, only an elective affinity can exist between the reality of material facts and symbolic actions. ${ }^{43}$ For Jürgen Habermas as well, the decisive distinction here from the first pattern is the importance of the symbolic dimension of human actions and events. The broadly neo-Kantian approaches of Weber and Parsons are especially equipped against the danger of not connecting empirical action systems with its intrinsic symbolic dimension. They operate with the notion that ideas and interests (Weber) or cultural values and motives (Parsons) interpenetrate in social orders. These approaches interpret institutionalised action as the selective realisation of cultural values under situational constraints. ${ }^{44}$

THE MARX PATTERN

The third pattern is the dialectically based, materialistic ontology of Marx and Engels. Their work should be understood in the context of Hegel. This ontology relates to relational, collectivistic epistemology. According to Vanberg, the ultimate difference here from the methodological individualism of the first and second patterns is the application of the "Emergenz Doctrin" (also true for the Durkheim pattern). This a priori thesis supposes an ontological reality leap. It means that because of the association and interweaving of people, new configurations and emergent phenomena come into being. These cannot be understood through explanation of the nature and the actions of the participating individuals. ${ }^{45}$ Decisive for this third pattern, and more or less like the second pattern, it is based on dialectically founded relationships. Bertell Ollman has especially emphasised this point. This is really the nub of our difficulty in understanding Marxism, whose subject matter is not simply society but society conceived of relationality. ${ }^{46}$ In analogy with the natural sciences and biology in particular, research on determinant and inevitable socio-historical laws is characteristic for this pattern, as it is for the Durkheim pattern.

\section{THE DURKHEIM PATTERN}

The fourth pattern regards the organically founded, functionalistic ontology of Durkheim. His philosophy should be understood in the context of the social philosophers of the French Enlightenment, including Voltaire, Rousseau, de Saint-Simon and Comte. ${ }^{47}$ The Durkheim ontology was also highly influenced by 19 th century biophysics. Social configurations (later social systems) are determined by biological necessities. His ontological point of view concerned a positivistic, collectivistic epistemology. ${ }^{48}$ Social and organic subsystems are primarily seen as serving the whole of which they are just a part. In other words, social wholes as groups are perceived as social facts 
that deliver the fundamental, irreducible social reality. They present the points of departure of social explanation. Analyses of phenomena are aimed towards the nature of their functionality for larger wholes. This pattern of thought inspires the recent debate on social cohesion and (social) exclusion, which is also important for modern public health. Graham Room explained its difference to the poverty approach by saying that research into poverty, in its modern scientific form, is primarily an AngloSaxon product of the 19 th century. It is closely associated with the liberal vision of society, under which society was seen by relevant intellectual and political elites as a Paretonian mass of atomised people engaged in competition within the market place. The goal of social policy was to ensure that each person had sufficient resources to be able to survive in this competitive arena. In contrast, notions of social exclusion are part of a continental-and perhaps more particularly a French-tradition of social analysis. Society is seen by the intellectual and political elite as a status hierarchy or as a number of collectivities, bound together by sets of mutual rights and obligations that are rooted in some broader Durkheim order. ${ }^{49}$

\section{The four patterns and public health}

Implicitly or explicitly, these four distinct philosophical patterns of thought underlie approaches in theory, policy and practice in various policy domains. This is also the case for public health. The patterns underlying thinking in public health are summarised in table 1.

THE SUBJECT MATTER OF PUBLIC HEALTH

In our opinion, the essence of a philosophy of modern public health concerns defining the right subject matter. This definition is directly connected to the application of a specific pattern of thought or a combination of patterns. Our propositions regarding: (1) individual subjects as social beings, and (2) the reciprocity between social conditions and actions of these subjects, refer respectively to a combination of the Marx and the Durkheim, and to the Weber and Marx patterns of thought. It should be noted that commonly used concepts such as facts, social, group, disease, subject, equality, and so on, have different meanings depending of the pattern of thought applied. Each pattern implies a specific connection between the ontological and epistemological points of view, which lie at the foundation of the assumed meanings. This must be the reason that the Evans Report refers not to equality, but to equity. The first concerns the equality of atomised subjects, as favoured in the United States. According to the Ottawa Charter, however, subjects are perceived as social beings, and equity refers to a feature of society, and consequently is the right term to use. The application in the United States based on the concept of equality is therefore not in line with the original Canadian principles of the health promotion policy.

Our proposals concerning public health and the significance of the concept of social quality imply a choice with respect to the patterns of thought in this specific domain. For example, the Pareto pattern is directly in contrast with the conceptualisation we propose. The economist Friedrich Hayek has implicitly explained this conclusion. As a true exponent of the Pareto pattern, he denies the possibility that as an adjective or a noun, the word social refers to aspects of the objective reality. In 1979, he argued, nobody knows what social in fact is. True is, a social market economy is no market economy, a social constitutional state is no constitutional state, a social conscience is no conscience, social justice is not a justice. ${ }^{50}$ In this kind of empirical realism, according to Andrew Collier, one denies the reality of underlying mechanisms and structures that do not appear in experience, but cause phenomena that do. A transcendental realist, by contrast, is one who claims that such mechanisms can be shown to be real by means of transcendental arguments. ${ }^{51}$

By applying the four distinctive patterns, we learn to understand why the leading medical paradigm and neo-monetarist economic proposals are complementary theoretical outcomes of the ontological and epistemological principles of the Pareto pattern. Douglas Weed also refers to this question. ${ }^{52}$ It is precisely this complementary nature of medical and economic approaches that widens the gap between the overall medical institutional capacity and the growing demand for services. This gap between ability and desirability, between medical expertise and medical ethics, is increasing daily and will continue to do so. ${ }^{53}$ Consequently, we need to reformulate ethics afresh in the light of new concepts about modern public health problems.

FOUCAULT AND PUBLIC HEALTH

The distinctions among the patterns also enable us to interpret Michel Foucault's ideas about power in relation to public health. Until the 1960s, Foucault dismissed suppositions about power concepts, whether of the right or

Table 1 Patterns underlying thinking in public health

\begin{tabular}{llll}
\hline $\begin{array}{l}\text { Pattern of } \\
\text { thought }\end{array}$ & Nature ontology & Nature epistemology & Health perspectives \\
\hline Pareto & $\begin{array}{l}\text { mechanistic-atomistic based } \\
\text { utilitarianism } \\
\text { intentionalistic based voluntarism }\end{array}$ & $\begin{array}{c}\text { positivistic orientation, methodological } \\
\text { individualism } \\
\text { hermeneutic orientation, relational } \\
\text { methodological individualism } \\
\text { positivistic orientation, relational } \\
\text { methodological collectivism } \\
\text { Marx }\end{array}$ & dialectically based materialism \\
Durkheim & organically based functionalism & disease perspection & illness perspective \\
\hline
\end{tabular}


of the left. For example, Ivan Illich's proposals concerning medical bureaucracies as causes of iatrogenesis constitutes only a small part of the whole public health story. ${ }^{54}$ Alan Sheridan concludes that according to Foucault, power, as such, does not exist, but in challenging existing notions of how societies operate, one is forced, in the first instance, to use the same word. Power is an effect of the operation of social relationships, between groups and between individuals. It is not unitary: it has no essence. Every group and every individual exercises power and is subjected to it. ${ }^{55}$ The outcomes are given in the subjection of individuals to power on the micro-level, through which individual subjects are constructed as citizens, prisoners, patients (the micro-physics of power). ${ }^{56}$ This concerns a interpretation that rejects the essence of the Marx and Durkheim patterns. Foucault also rejects the principles of the Pareto pattern. In his ideas, the asylum in the age of new positivism was not primarily the place for observation, diagnosis and treatment of patients. It was the juridical space where one was accused. Madness was to be punished inside the asylum. A century later, this positivism imposed its myths of scientific objectivity and disguised the fact that it was a demonstration of magic. In line with the suppositions regarding the nature and application of power, this could happen because of the complicity of the patients themselves. $^{57}$ This paved the way for the subjection of patients to medical truth, articulated by the queen of all sciences: medical science. She pretends to be the science that distinguishes between pathology (abnormality) and health (normality). These judgements are accepted and inscribed in the body of the people themselves. In our opinion, Foucault's theory is a specific interpretation of the Weber pattern of thought.

\section{Modern public health}

In the 19th century, the old public health orientation towards biological hygiene of urban and domestic spaces was based on natural scientific epidemiology. This single scientific orientation simply cannot conceive of public as a reality of social configurations. In this perspective, as a noun public remains a metaphor for an aggregation of individuals. It therefore logically dismisses communities as social configurations with specific characteristics attributable to given political, economic and social relationships and related norms, values and orientations. ${ }^{58}$ We do agree with Steve Wing, that in this intellectual context, public is an aggregate of exposed and unexposed (atomised) individuals. Questions about where the exposures come from, why certain groups are exposed and not others, who benefits from producing the exposures, or what other change occurs to produce the exposures are not of [that] epidemiological interest." ${ }^{\text {59 }}$

THE CASE OF THE BRONX

Epidemiology explains little, for example, about human circumstances in the Bronx district of New York City. In terms of public health, it has little to say about the consequences of local circumstances for the health of its inhabitants. Jonanthan Kozol presents a meaningful picture that would be achieved through epidemiology. "In 1991, 84 people, more than half of whom were 21 or younger, were murdered in the precinct. A year later, ten people were shot dead on a street called Beekman Avenue, where many of the children I have come to know reside. On Valentine's Day of 1993, three more children and three adults were shot dead on the living room floor of an apartment six blocks from the run-down park that serves the area. What is it like for children to grow up here?" ${ }^{60}$ And people who have to go to health care institutions in the Bronx are confronted with "a cesspool and which has also lost accreditation several times ... waiting in the emergency room two days to be admitted ... with all the other people who were waiting. Sick children vomiting up their food. Men with gunshot wounds. People with AIDS. Old people coughing up their blood."

In a Paretonian world of atomised subjects, everyone in the Bronx is supposed to have the same equal chances in life. Everyone has an equal right not to use these chances and to die on the streets. Outcomes of health merely refer to the actions of individuals. As aggregates, they constitute the Bronx as a social phenomenon and their actions fully explain the living conditions of the Bronx. Our hypothesis is that using more than one pattern of thought will enable us to appreciate the circumstances in the Bronx in their full range and depth. From there, one can begin to picture policies and strategies for changing the conditions that improve or undermine health. The Bronx illustrates that choosing specific policies-or indeed, not choosing any-can better be understood by explication of the ontological perspective selected and its epistemology. The deprived, complex social situation in the Bronx may constitute an argument for working with the social quality theory, to articulate the subject matter of public health in our recently and profoundly transformed modern societies. It delivers a real chance for better understanding these circumstances as well. Possibly, that is the reason Vincente Navarro strongly recommends the first book concerning this approach. ${ }^{62}$

First of all, we must understand the processes of modernisation in order to rekindle the debate on public health. The majority of debates on epidemiology and public health ignore these processes. In other words, they ignore the social realities of modern daily life. The social quality approach is meant to develop a theory with which to conceptualise these new realities. To adequately tackle these processes of modernisation, modern public health needs a new orientation, distinct from the old public health (biological hygiene) and from the recent public health approaches (individualistic health promotion). Modern public health means considering modern problems of social and economic relationships, new forms of inequalities, exclusion and the marginalisation of many groups of urban inhabitants. Modern is about these new 
social, economic, cultural and political phenomena.

INEQUITY AND MODERN PUBLIC HEALTH

For a new comprehension the outcome of the interaction between social systems and living conditions, according to German social scientists, the Marxist concept of class and the Weber concept of status do not suffice. ${ }^{63}$ Ulrich Beck states that we are witnessing a shift from the industrial production of national welfare in the context of social classes to a production of worldwide risks for everyone. As a consequence of the modernisation of industrial processes and actual state interventions, traditional classes in Western Europe are vanishing. Growing individualisation is a consequence of modern economic relations, not a result of so called postmodern philosophy as a deliberately chosen cultural shift. Individualisation and related monetarist attitudesstimulating a growing inequality while undermining social possibilities to combat it-result from this profound change. According to British scientists, the related social disparities constitute the heart of the matter in modern public health. Referring to these disparities, Michael Benzeval argues that in Britain death rates at all ages are two to three times higher among disadvantaged social groups than their more affluent counterparts. People living in disadvantaged circumstances can also expect to experience more illness and disability. What is particularly worrying, however, is that economic inequality seems to be growing more quickly in Britain than at any time since the second world war. ${ }^{65}$

The debate on inequalities of health forces us to develop new theories about cause and effect. Michael Burry especially refers to this need. This view conveys the idea that little improvement in health has occurred in the post-war period, and is unlikely to in the future without a major redistribution of income and wealth. Couched in these terms, the health inequalities debate has sometimes threatened to become a sterile one. There is also the possibility that reductions in health provision may be encouraged by health inequality arguments, which point to the apparent inability of welfare states to effect positive change. Having said this, some medical sociologists have recently been developing new and fresh lines of research, which attempt to overcome some of these difficulties. They have investigated, in particular, the important question of social and cultural change that has dogged the heels of the health inequalities debate. Referring to $M$ Blaxter and S Macintyre, Burry emphasises the consequences of recent disorganised capitalism, which is marked by changing class structures and the undermining of local and regional economies and the social structures dependent on them. ${ }^{67}$

\section{Back to Weed's discussion}

PRACTICAL EVIDENCE

Douglas Weed concluded that Nijhuis and Van der Maesen did not illustrate their disclosure claim with an example of how the public health decision making was made better by revealing the ontological orientation(s) of the decision maker. ${ }^{52}$ Our discussion of a philosophy of modern public health attempts to demonstrate that using the four patterns of thought sheds light on particular modes in which public health problems are perceived and the resulting choices made for policies and strategies. We have argued that public health, both with epidemiology as its scientific core, and rooted in Paretonian thought, is not logically orientated towards understanding social conditions that improve or undermine health and prevent ill health. It does not touch the heart of modern public health. We have so far limited ourselves to a theoretical support of our position. Our next step should indeed be to produce scientific evidence for our hypothesis through analysis of concrete cases of problematic public health situations.

\section{MEDICAL ETHICAL QUESTIONS}

We do fully agree with Weed's conclusion that the disclosure claim should include both epistemological and ethical questions. In his presentation of cancer screening as an example of public health, Weed refers to Rose's prevention paradox: screening may deliver benefits for populations, but may also cause harm to subjects undergoing it. From our perspective a screening programme should be seen as a medical system of procedures aiming at diagnosis of disease. As for its medical outcome for people, it therefore has to be appreciated as a medical strategy. Weed's ethical questions of course remain extremely relevant for the field of medical policy. We would like to state that in tackling ethical issues, we have to distinguish between medically orientated policies regarding medical procedures and public health policies regarding the social quality aspects of health related systems as a whole.

Dealing with ethical questions in medicine is complex, as the basic frame of reference here is Pareto thought, a perspective in which ethical questions are reduced to the interaction of moral preferences of individual subjects. Embedded in this pattern, ethical considerations are highly problematic. According to Charles Taylor, the specific combination of ethics and individuality is based on the natural science model. Because following the argument in favour of a theory in natural science requires that we neutralise our own anthropocentric reactions, we too easily conclude that the arguments in the domain of practical reason ought not to rely on our spontaneous moral reactions. ${ }^{69}$ According to Taylor, we need to redress our ability to make qualitative discriminations in order to distinguish between the good and the bad. ${ }^{70}$ To determine our actions only from the scientific standpoint, for instance, based on knowledge of side effects, may to a certain extent contribute to ethical questions related to cancer screening. Scientific evidence of this sort certainly is no solution for the social and health problems of the children of the Bronx. 
ETHICAL QUESTIONS OF PUBLIC HEALTH

Can the patterns of thought distinguished above be helpful in solving ethical questions of public health? The Durkheim pattern will also cause several problems. In this perspective, social facts are entities sui generis, with an intrinsic explanatory power, independent of the constitutive position of interacting subjects. According to Durkheim, societies conceived as configurations of social facts are the source of moral power. ${ }^{71}$ According to Habermas, Durkheim here created his own paradox. In the Durkheim perspective, the present day increase of anomic social circumstances should be seen as outcomes of processes of these entities themselves. How could these negative processes of social differentiation function as sources for new moral codes?

For ethical questions of modern public health, it may be of more interest to refer to the Weber pattern of thought. Weber particularly distinguished between is and ought, a distinction that received enormous attention in the recent history of social philosophy. Arnold Brecht notes, in his classic study on political philosophy, "The concept of ought, qua concept, is a merely formal mode of thought, grammatically expressed by an imperative, just as the formal concepts of past and future are grammatically expressed by preteritum and futurum. No particular substantive content can be derived from a formal mode of thought; it lends itself to any type of content, denying itself to none." ${ }^{73}$ With Brecht's thesis in mind, our answer to Douglas Weed should be that this theoretical position explains why ethical questions cannot derive from ontological and epistemological questions. For these, we need a different level of reasoning. We seem to have to distinguish between ethical, ontological and epistemological questions and principles.

For the debate on ethical questions, it makes sense to refer to Petersen and Lupton's critical discussion of recent approaches of public health, for example, the Healthy Cities Project. Their discussion is based on Foucault's perspective. New public health can be seen as but the most recent of a series of regimes of power and knowledge that are oriented to the regulation and surveillance of individual bodies and the social body as a whole. In their opinion, common new public health is completely focused on the so called healthy bodies and strategies for change individual lifestyle. ${ }^{74}$ The environmental discourses also tend to rely upon traditional modernist assumptions in suggesting that the future may be rationally predicted, that the gathering of information is enough to control future effects as long as the appropriate "strategies" are used. ${ }^{75}$ According to Petersen and Lupton, the new public health is at its core a moral enterprise that involves prescriptions about how we should live our lives and conduct our bodies, both individually and collectively. Part of the broad appeal of the new public health is undoubtedly attributable to its adoption of a language of "empowerment" and a rhetoric advocating social and environmental change. ${ }^{76}$ They further remark, there has been little analysis and critique of the concept of "community participation" in the new public health literature. This attests to the difficulty of articulating theories and developing social practices that do not conform to the norms of neo-liberal democratic discourse. ${ }^{77}$

ETHICS AND SOCIAL QUALITY

Foucault's conceptual scheme is highly stimulating for analysing propositions and points of view on ethical questions. The position taken by Petersen and Lupton however also implies a form of relativism. The world is appreciated as totally contingent and dependent on the structure of human minds. Claims for an objective reality are judged as arrogant. Doyal and Gough commented implicitly on Foucault's perspective by stating the consistent relativistone who regards the whole of social life as a "construction", each aspect of which has no more or less veracity than the other-enters a moral wasteland into which few have feared to tread. ${ }^{78}$ Roy Bhaskar's conclusion concerning the epistemic fallacy can be applied to Peterson's and Lupton's study as well. Statements about being can be reduced to or analysed in terms of statements about knowledge - that is, that ontological questions can always be transposed into epistemological terms. This results in the systematic dissolution of the idea of a world independent of but investigated by science. $^{79}$

From our perspective, society is to be conceived both as the totality of conditions of human actions and as the result of human actions. For a valid comprehension of society as a subject of public heath, the multi-layered mechanisms that can change these human actions and strategies need to be analysed. The challenge of our modern enterprise of public health is to improve social conditions related to health. In doing so, we are in fact meeting our values and norms, in other words, the ethical questions of public health. The social quality theory tries to respond to this challenge. In our opinion, modern public health, based on a theory of which we have attempted to outline some principles, has to play an important part in this moral endeavour.

1 Weed DI. Towards a philosophy of public health. $f$ Epidemiol Community Health 1999;53:99-104.

2 Nijhuis HGJ, Van der Maesen LJG. The philosophical foundations of public health: an invitation to debate. $\mathcal{F}$ Epidemiol Community Health 1994;48:1-3.

3 Murray CLJ, Lopez AD, eds. The global burden of disease. Vol 1. Boston: Harvard University Press, 1996.

4 Population health looking upstream. Lancet 1994;343:429 30.

5 Nuffields Institute for Health. The Leeds declaration. Leeds: University of Leeds, 1993.

6 Backett K, Currie C, Hunt S, et al. Changing the public Backett K, Currie C, Hunt S, et al.
health. Chichester: John Wiley, 1989:6.

7 Renton A. Epidemiology and causation: a realist view. $\mathcal{F}$ Epidemiol Community Health 1994;48:79-85, 84

8 Institute of Medicine. The future of public health. Washington DC: National Academy Press, 1988

9 Krieger N. Epidemiology and the web of causation: Has anyone seen the spider? Soc Sci Med 1994;39:887-903.

10 Lilienfeld AM, Lilienfeld DE. Foundations of epidemiology. New York: Oxford University Press, 1970:4, 12, 48, 90.

11 McKeown T. The role of medicine: Dream, mirage or memesis? London: Nuffield Provincial Hospital Trust, 1976:79.

12 McKeown T. The origins of human disease. Blackwell: Oxford, 1988.

13 Krieger N. Epidemiology and the web of causation: Has anyone seen the spider? Soc Sci Med 1994;39:894.

14 Krieger N. Epidemiology and the web of causation: Has anyone seen the spider? Soc Sci Med 1994;39:899. 
15 Susser M, Susser E. Choosing a future for epidemiology: from black box to Chinese boxes and eco-epidemiology.

16 Susser M. Does risk factor epidemiology put epidemiology at risk? Peering into the future. $\mathcal{F}$ Epidemiol Community Health 1998;52:608-11.

17 Ottawa Charter for Health Promotion. Ottawa: World Health Organisation, Health and Welfare Canada, Canadian Public Health Association, 1986

18 Evans JR, ed. Toward a shared direction of health in Ontario: Report of the Ontario Health Review Panel. Toronto: Ontario Council for Health, 1987.

19 Doyal L, Gough I. A theory of human need. London: MacMillan Education, 1991:54.

20 Frankenberg R. Your time or mine? An anthropological view of the tragic temporal contradictions of biomedical practice. Int 7 Health Serv 1988; 1:11-35.

21 Nijhuis HGJ. Voorwaarden voor Vernieuwing van Public Health: Een wetenschaps- en maatschappijtheoretisch perspectief. Den Haag: Uitgeverij Elmar BV, 1994:150.

22 Habermas J. Theorie des kommunkativen Handelns: Band 2. Frankfurt am Main: Suhrkamp Verlag, 1982:470-516.

23 Beaglehole R, Bonita R. Public health at the crossroads: which way forward? Lancet 1998;351:590-2.

24 Blaxter M. Health and lifestyle. London: Tavistock Routledge, 1990

25 Baum F. Healthy cities-Where are we going? Healthy Cities for All 1992;4:1-18 (Liverpool).

26 Van der Maesen, LJG. The healthy cities approach: a proposal to develop the reciprocity between theory and practice. A paper as a result of the 7th International WHO Healthy Cities Symposium, 9-12 fune 1992, in Copenhagen. Amsterdam: SISWO, 1992.

27 Bhaskar R. The Possibility of naturalism: a philosophical critique of the contemporary human sciences. Brighton: The Harvester Press, 1979:43-4.

28 Sève L. Man in Marxist theory and the psychology of personality. Brighton: The Harvester Press, 1978:139.

29 Gruber HE, Vonèche J, eds. The essential Piaget. New York: Basic books, 1977:435-6.

30 Von Beyme K. Theorie der Politik im 20 fahrhundert. Frankfurt am Main: Suhrkamp Verlag, 1992:351.

31 Beck W, Van der Maesen LJG, Walker AC, eds. The social quality of Europe. The Hague/Boston: Kluwer Law International, 1997: 268. Reprinted as: The social quality of Europe. Bristol: The Policy Press, 1998.

32 Walker AC. Social quality and the future of The European Union. European fournal of Social Quality (in press).

33 Bhaskar R. The Possibility of naturalism: a philosophical critique of the contemporary human sciences. Brighton: The Harvester Press, 1979:43-4:51.

34 Beck W, Van der Maesen LJG, Thomése F, Walker AC, eds. Questioning the social quality of Europe. The Hague/Boston: Kluwer Law International (in press).

35 Baum F. Researching public health: behind the qualitativequantitative methodological debate. Soc Sci Med 1995;40 quantita.

36 Vanberg V. Die Zwei Soziologien: Individualismus und Kollektivismus in der Sozialtheorie. Tübingen: JCB Mohr Kollektivismus in der

37 Van der Maesen LJG. Transformatie van de Gezondheidszorg in Nederland tussen 1974 en 1987. Assen/Maastricht: Van in Nederland tussen 1974

38 Finer SE. Vilfredo Pareto: sociological writings. Oxford: Basil Blackwell, 1976:31

39 Röd W. Descartes: die Genese des Cartesianischen Rationalismus. München: Verlag CH Beck, 1964:47.

40 Bhaskar R. The Possibility of naturalism: a philosophical critique of the contemporary human sciences. Brighton: The Harvester Press, 1979:36.

41 Vanberg V. Die Zwei Soziologien: Individualismus und Kollektivismus in der Sozialtheorie. Tübingen: JCB Moh (Paul Siebeck), 1974:86

42 Henderson L. Pareto's general sociology: a physiologist's interpretation. New York: Russell and Russell, 1935.

43 Gerth HH, Wright Mills C. From Max Weber: essays in sociology. New York: Oxford University Press, 1958:62.

44 Habermas J. Between facts and norms. Contributions to a discourse theory of law and democracy. Cambridge, MA: The MIT Press, 1996:66.

45 Vanberg V. Die Zwei Soziologien: Individualismus und Kollektivismus in der Sozialtheorie. Tübingen: JCB Moh (Paul Siebeck), 1974:159.

46 Ollman B. Alienation: Marx's conception of man in capitalist society. 2nd ed. Cambridge: Cambridge University Press, 1976:14.
47 Vanberg V. Die Zwei Soziologien: Individualismus und Kollektivismus in der Sozialtheorie. Tübingen: JCB Mohr (Paul Siebeck), 1974:137-9.

48 Bhaskar R. The Possibility of naturalism: a philosophical critique of the contemporary human sciences. Brighton: The Harvester Press, 1979:38.

49 Room G. Poverty and social exclusion: the new European agenda for policy and research. In: Room G, ed. Beyond the threshold: the measurement and analysis of social exclusion. Bristol: The Policy Press, 1995:1-10, 6 .

50 Hayek F (by N Piper). Die unheimliche Revolution. Die Zeit 1997:37;5 September.

51 Collier A. Critical realism. An introduction to Toy Bhaskar's philosophy. London: Verso, 1994:26.

52 Weed DI. Towards a philosophy of public health. $f$ Epidemiol Community Health 1999;53:99-104.

53 Van der Maesen LJG. Transformatie van de Gezondheidszorg in Nederland tussen 1974 en 1987. Assen/Maastricht: Van Gorcum, 1987:301-2.

54 Illich I. Limits to medicine: medical nemesis. The expropriation of health. London: Marion Boyars, 1976.

55 Sheridan A. Michel Foucault: the will to truth. London: Tavistock Publications, 1980:218.

56 Foucault M. Surveiller et punir: Naissance de la prison. Paris: Gallimard, 1975:139-40.

57 Foucault M. Histoire de la folie à l'âge classique. Paris: Gallimard, 1975:263-9.

58 Burrage H. Epidemiology and community. Soc Sci Med 1987;8:895-903.

59 Wing S. Whose epidemiology, whose health? Int $\mathcal{F}$ Health Serv 1998;28:241-52.

60 Kozol J. Amazing grace: the lives of children and the conscience of a nation. New York: Crown Publishers, 1995:5.

61 Kozol J. Amazing grace: the lives of children and the conscience of a nation. New York: Crown Publishers, 1995:16.

62 Navarro V, Beck W, van der Maesen L, et al, eds. The social quality of Europe. F Eur Soc Pol 1999;9:89-90.

63 Kreckel R. Politische Soziologie der sozialen Ungleicheit. Frankfurt: Campus Verlag, 1992:52-66.

64 Beck U. Risikogesellschaft:auf dem Weg in eine andere Moderne. Frankfurt am Main: Suhrkamp Verlag, 1986:63, 119, 154.

65 Benzeval M, Judge K, Whitehead M, eds. Tackling inequalities in health: an agenda for action. London: King's Fund, 1996: xxvii. Also: Walker AC, Walker C, eds. Britain divided: the growth of social exclusion in the 1980s and 1990s. London: CPAG Ltd, 1997:3. Finally: Townsend P, Gordon $\mathrm{D}$, Bradshaw J, et al. Absolute and overall poverty in Britain in 1997: what the populations themselves say. Report of the Second MORI Survey. Bristol: University of Bristol, 1997.

66 Burry M. Health and illness in a changing society. London: Routledge, 1997:71-2.

67 Blaxter M. Inequality in health and the problem of time. Med Soc News 1993;18:12-14. Furthermore: McIntyre S. The patterning of health: the role of the social sciences. $\mathcal{F}$ Public Health Med 1994;16:393-415.

68 Reference withdrawn

69 Taylor C. Sources of the self: the making of the modern edentity. Cambridge: Press Syndicate of the University of Cambridge, 1994:73.

70 Taylor C. Sources of the self: the making of the modern edentity. Cambridge: Press Syndicate of the University of Cambridge, 1994:86.

71 König R. Einleitung. In: Durkheim E. Regeln der soziologische Methode. Berlin: Luchterhand, 1965:57.

72 Habermas J. Between facts and norms. Contributions to a discourse theory of law and democracy. Cambridge, MA: The : 178

73 Brecht A. Political theory: the foundations of twentieth-century political thought. Princeton: Princeton University Press, 1959:211.

74 Petersen A, Lupton D. The new public health: health and the self in the age of risk. London: Sage Publications, 1996:23.

75 Petersen A, Lupton D. The new public health: health and the self in the age of risk. London: Sage Publications, 1996:89.

76 Petersen A, Lupton D. The new public health: health and the self in the age of risk. London: Sage Publications,

77 Petersen A, Lupton D. The new public health: health and the self in the age of risk. London: Sage Publications, 1996:173. 78 Doyal L, Gough I. A theory of human need. London: MacMillan Education, 1991:54.

79 Bhaskar R. A realist theory of science. Brighton: Harvester Press, 1978:56. 